\title{
Transcriptional analysis of the porcine $T T I D$ gene and association of different TTID genotypes with carcass traits
}

\author{
J. Wang', Y.-P. Feng' ${ }^{2}$ B. Zuo ${ }^{2}$, Y.-Z. Xiong ${ }^{2}$ and C.-Y. Deng ${ }^{2}$ \\ ${ }^{1}$ Department of Bio-Engineering, Faculty of Environmental Engineering, \\ Wuhan Textile University, Wuhan, Hubei Province, China \\ ${ }^{2}$ Key Laboratory of Swine Genetics and Breeding, Ministry of Agriculture, \\ Key Laboratory of Agricultural Animal Genetics and Breeding, \\ Ministry of Education, Huazhong Agricultural University, Wuhan, \\ Hubei Province, China \\ Corresponding author: C.-Y. Deng \\ E-mail: wes2100@webmail.hzau.edu.cn
}

Genet. Mol. Res. 13 (1): 1195-1202 (2014)

Received December 19, 2012

Accepted July 23, 2013

Published February 27, 2014

DOI http://dx.doi.org/10.4238/2014.February.27.4

\begin{abstract}
The titin immunoglobulin domain (TTID) protein localizes to the $\mathrm{Z}$ line in muscle and binds to alpha-actinin and gamma-filamin. It plays an indispensable role in stabilizing and anchoring of thin filaments. In this study, the 5'-regulatory region of the porcine TTID gene was analyzed with bioinformatic methods. Another objective of this study was to further investigate the polymorphism in the intron 6 of the porcine TTID gene. We determined allele frequency among six Chinese porcine purebreds. The polymorphisms were genotyped in a population of $280 \mathrm{~F}_{2}$ pigs representing two Large White $\mathrm{x}$ Meishan reference families. Different TTID genotypes were significantly associated with carcass traits, including skin percentage $(\mathrm{P}<0.05)$, loin eye area $(\mathrm{P}<0.05)$, and average skin thickness $(\mathrm{P}<0.01)$. Our study will continue to lay
\end{abstract}


the groundwork for further investigations into the detailed function of the porcine TTID gene.

Key words: Porcine; Titin immunoglobulin domain protein (TTID); Polymerase chain reaction-restriction fragment length polymorphism; Association analysis; Carcass traits

\section{INTRODUCTION}

Sarcomeres are the basic contractile units of the striated muscle, which is composed of thin actin and thick myosin filaments. The sarcomere is controlled by many structural proteins, such as titin, nebulin and others (McElhinny et al., 2005). Titin is a giant protein that extends to one and a half of the length of the sarcomere; the titin $\mathrm{N}$-terminus is embedded within the Z-disk and its C-terminus within the M-line (Gautel et al., 1999). The titin protein contains several immunoglobulin (Ig)-like domains and some unstructured peptide sequences (Salmikangas et al., 1999). Human titin immunoglobulin domain (TTID) protein was the first titin protein studied: it is a novel $57-\mathrm{kD}$ cytoskeletal protein that co-localizes and directly interacts with alpha-actinin in sarcomeric I-bands (Salmikangas et al., 1999). The human TTID gene mapped to the human chromosome 5q31, between markers AFM350yB1 and D5S500; it contains 10 exons that extend over $19 \mathrm{~kb}$ (Salmikangas et al., 1999; Godley et al., 1999). Studies have shown that TTID plays an indispensable role in stabilizing and anchoring of thin filaments, which may be a prerequisite for correct Z-disc organization (Salmikangas et al., 2003). In porcine, Davoli et al. (2002) only mapped the gene to SSC 2q26.

Our previous study has shown that porcine TTID mRNA is expressed at the highest level in skeletal muscle and at the second-highest level in the heart (Wang et al., 2013), consistent with findings of TTID expression in human tissues (Salmikangas, 2001). In addition, a T978C single nucleotide polymorphism (SNP) in intron 6 of porcine TTID gene has been identified by HinfI PCR-RFLP. The distribution of the allele frequency in four different pig breeds has been analyzed by Wang et al. (2013), indicating that the Chinese breed Meishan have a higher frequency of the A allele (77.4\%), whereas Large White and Landrace pigs display higher frequencies of the B allele (100 and 98.2\%, respectively). Association analysis showed that some T978C SNP genotypes were significantly associated with meat $\mathrm{pH}$ (musculus biceps femoris) $(\mathrm{P}<0.05)$, meat color value (musculus biceps femoris) $(\mathrm{P}<0.05)$, or water moisture (musculus biceps femoris) $(\mathrm{P}<0.05)$ (Wang et al., 2013).

The current study was designed to further analyze the deduced protein sequence of porcine TTID and to investigate possible effects of the T978C polymorphism in porcine TTID intron 6 on carcass traits. This study will contribute additional knowledge of the function of the porcine TTID gene.

\section{MATERIAL AND METHODS}

The TFSEARCH (http://www.cbrc.jp/research/db/TFSEARCH.html) and TESS (http://www.cbil.upenn.edu/cgi-bin/tess) programs were used to analyze putative transcriptional factor-binding sites in the nucleotide sequence of the 5'-flanking region of the porcine TTID gene (GenBank accession No. DQ157551). 
Two $F_{2}$ cross-breeding population between Large White and Meishan pigs were generated in 2000 and 2003, respectively, and consisted of 280 animals (Yang et al., 2010). All animals had unlimited access to food and water and were born and raised in Huazhong Agriculture University Jingpin Pig Station. Pigs were slaughtered when they were 180 days old and measured according to the methods of Xiong and Deng (1999). The measured carcass traits were the following: birth weight, dressing percentage, skin percentage, bone percentage, internal fat rate, fat meat percentage, lean meat percentage, ratio of lean meat to fat meat, carcass length, rib numbers, loin eye height, loin eye area, average skin thickness, backfat thickness at shoulder, backfat thickness at thorax-waist, backfat thickness at buttock, backfat thickness at 6-7th thorax, and average backfat thickness (measured at three points: backfat thickness at shoulder, backfat thickness at thorax-waist, backfat thickness at buttock).

Blood samples were collected from $280 \mathrm{~F}_{2}$ individuals. Genomic DNA was isolated by phenol/chloroform purification protocols (Sambrook et al., 1989) and stored at $-20^{\circ} \mathrm{C}$.

The intron 6 of porcine TTID gene was amplified by PCR with the primers GenomicF (5'-CTGCTCCCAATTCAGAAAA-3') and Genomic-R (5'-GGATGAGTGATGATTTGTT TG-3'). PCR amplification was carried out in a $25-\mu \mathrm{L}$ volume containing standard $1 \mathrm{X}$ PCR buffer and 1 IU Taq polymerase (Jingmei Biotech, China), $200 \mu \mathrm{M}$ of each dNTP, 10 pmol of each primer, and $1.0 \mu \mathrm{L}$ genomic DNA. The template was denatured for $4 \mathrm{~min}$ at $94^{\circ} \mathrm{C}$, followed by 35 cycles of amplification at $94^{\circ} \mathrm{C}$ for $50 \mathrm{~s}, 59^{\circ} \mathrm{C}$ for $60 \mathrm{~s}, 72^{\circ} \mathrm{C}$ for $50 \mathrm{~s}$, and terminated with an additional extension step for $10 \mathrm{~min}$ at $72^{\circ} \mathrm{C}$. A fragment of $1402 \mathrm{bp}$ was amplified in this way, and three genotypes of T978C SNP were identified as AA (44, 519, and $839 \mathrm{bp}), \mathrm{AB}(44,519,838,411$, and $428 \mathrm{bp})$, and BB (44, 519, 411, and $428 \mathrm{bp})$ by PCRHinfI-RFLP as previously described (Wang et al., 2013).

The association between genotype and carcass and meat-quality traits was performed with a least-square method (GLM procedure, SAS 8.0). The additive and dominance effects were estimated using the REG procedure of SAS 8.0. The additive effect was defined as $-1,0$, and 1 for $\mathrm{AA}, \mathrm{AB}$, and $\mathrm{BB}$, respectively, and the dominance effect represented as $1,-1$, and 1 for $\mathrm{AA}, \mathrm{AB}$ and $\mathrm{BB}$, respectively. The statistical model was assumed to be the following:

$$
\mathrm{Y}_{\mathrm{ijk}}=\mu+\mathrm{S}_{\mathrm{i}}+\mathrm{F}_{\mathrm{j}}+\mathrm{G}_{\mathrm{k}}+\mathrm{b}_{\mathrm{ijk}} \mathrm{X}_{\mathrm{ijk}}+\mathrm{e}_{\mathrm{ijk}}
$$

where $Y_{i j k}$ is the observed values of traits; $\mu$ is the least-square mean; $S_{i}$ is effect of sex (i=1 for male and 2 for female); $F_{j}$ is the effect of family; $G_{k}$ is the effect of genotype (K $=\mathrm{AA}, \mathrm{AB}$ and $\mathrm{BB}) ; b_{i j k}$ is the regression coefficient of the slaughter age; $X_{i j k}$ is the slaughter age; $e_{i j k}$ is the random residual (Liu, 1998).

\section{RESULTS}

Sequence analysis for the 5'-flanking region upstream of the transcriptional start site revealed putative binding motifs for several transcription factors: one site each for activating protein-1 (AP1), hairy and enhancer of split 1 (HES1), Yin Yang 1 (YY1), and a CACCC box; three sites each for CCAAT/enhancer-binding protein $\beta(\mathrm{C} / \mathrm{EBP} \beta)$ and the SP1 transcription factor (Figure 1). 


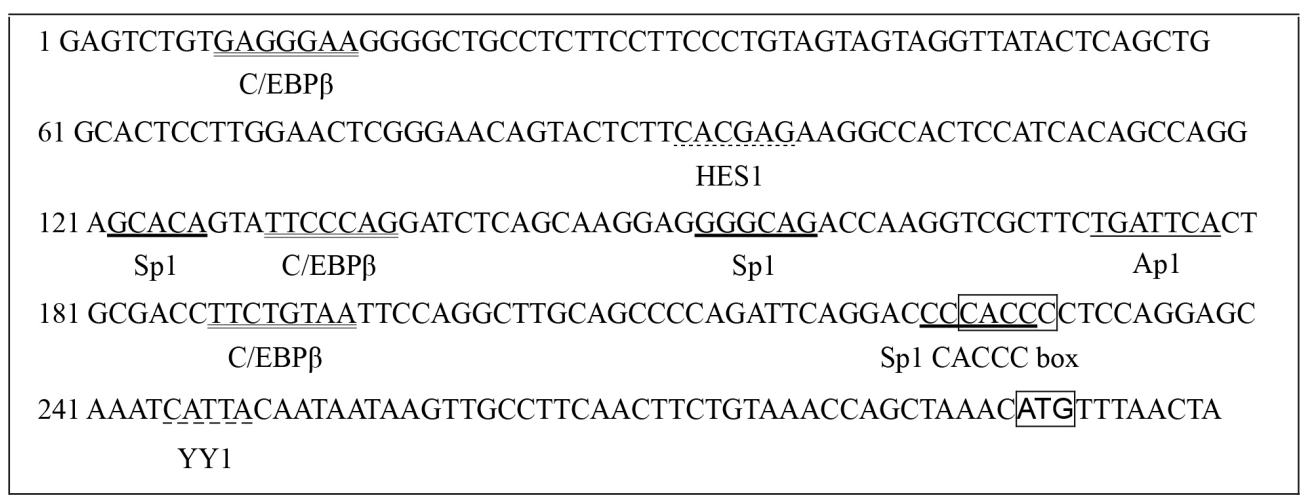

Figure 1. Nucleotide sequence of the 5'-flanking region of the porcine TTID gene. Potential transcriptional elements are underlined.

The result of the PCR amplification of the 1402-bp fragment is shown in Figure 2. The T978C polymorphisms were analyzed by PCR-HinfI-RFLP (see Figure 3).

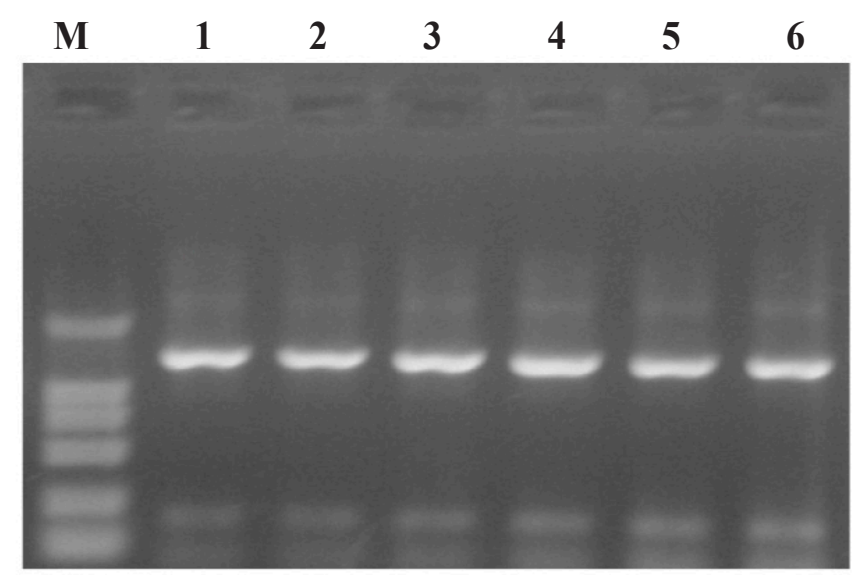

Figure 2. Amplified fragment of $\mathrm{F}_{2}$ generation from the Large White $\mathrm{x}$ Meishan resource family; Lane $M=\mathrm{DL} 2000$ maker. Lane $M=$ DNA DL2000 markers (100, 250, 500, 750, 1000, and 2000 bp); lanes 1-6 = amplified fragment of part samples from resource family, $1402 \mathrm{bp}$.

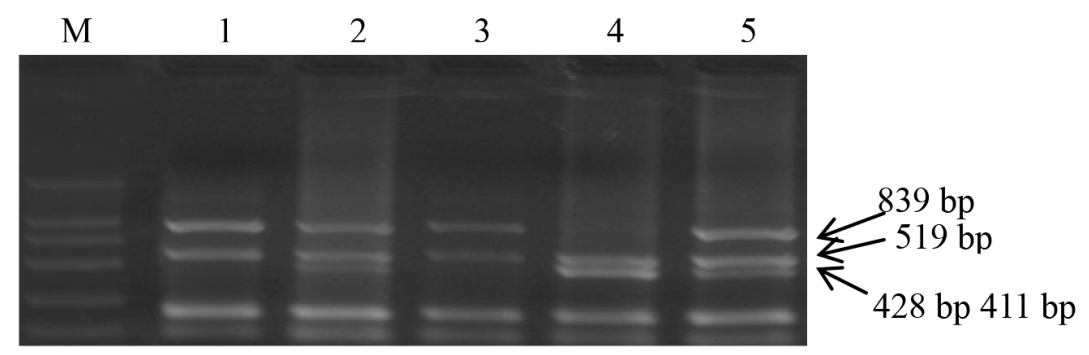

Figure 3. Agarose gel electrophoresis (1.5\%) showing the HinfI-RFLP results of the TTID gene. Lane $M=$ DNA marker DL2000; lanes 1, 3 = genotype $A A, 839,519,44$ bp; lanes 2, 5 = genotype $A B, 839,519,428,411,44$ bp; lane 4 = genotype $B B, 519,428,411,44 \mathrm{bp}$. 
The allele distribution of the porcine TTID polymorphism in 87 unrelated pigs was analyzed. The results of this analysis indicated that all six porcine purebreds in this site were polymorphic at the TTID locus (Table 1). Four breeds (Yangxin, Qingping, Wannanhua, and Bamei pigs) comprised three genotypes (AA, AB and BB), 2 breeds (Erhualian and Jianli) had no genotype $\mathrm{BB}$, which is roughly consistent with previous studies (Wang et al., 2013). The allele frequencies of this polymorphism displayed difference in the six breeds: Erhualian and Jianli pigs had 86.4 and $95 \%$ frequency, respectively, of the $A$ allele, higher frequencies than were present for this allele in the other four breeds (Table 1).

Table 1. Distribution of HinfI-RFLP genotype and allele frequencies among six pig breeds.

\begin{tabular}{lcccccr}
\hline Breed & Number & Genotype $A A$ & Genotype $A B$ & Genotype $B B$ & $A$ allele frequency $(\%)$ & $B$ allele frequency $(\%)$ \\
\hline Erhualian & 11 & 8 & 3 & 0 & 86.36 & 13.64 \\
Jianli & 20 & 18 & 2 & 0 & 95.00 & 5.00 \\
Yangxin & 13 & 6 & 5 & 2 & 65.38 & 34.62 \\
Qingping & 14 & 2 & 8 & 4 & 42.86 & 57.14 \\
Wannanhua & 18 & 5 & 12 & 1 & 36.11 & 38.89 \\
Bamei & 11 & 1 & 6 & 4 & 36.36 & 63.64 \\
\hline
\end{tabular}

A total of $280 \mathrm{~F}_{2}$ pigs of a Large White $\mathrm{x}$ Meishan resource population were used to identify polymorphisms by PCR-HinfI-RFLP. Of this population, 49 were of genotype AA, 129 of $\mathrm{AB}$, and 102 of $\mathrm{BB}$, thus corresponding to relative genotype frequencies of $\mathrm{AB}>\mathrm{BB}>$ AA in this resource population.

The mean weight of $280 \mathrm{~F}_{2}$ pigs was $86.8 \mathrm{~kg}(\mathrm{SD}=8.3)$, and the association analysis results are listed in Table 2 . As can be seen from Table 2, the HinfI SNP was significantly associated with skin percentage $(\mathrm{P}<0.05)$, loin eye area $(\mathrm{P}<0.05)$, and average skin thickness $(\mathrm{P}<0.01)$.

Table 2. Statistical analysis of TTID HinfI-RFLP genotypes with carcass traits.

\begin{tabular}{|c|c|c|c|c|c|}
\hline \multirow[t]{2}{*}{ Traits } & \multicolumn{3}{|c|}{ TTID HinfI-RFLP genotype } & \multicolumn{2}{|c|}{ Genetic effects } \\
\hline & Genotype $A A$ & Genotype $A B$ & Genotype $B B$ & Additive & Dominance \\
\hline BWT & $1.108 \pm 0.054$ & $1.109 \pm 0.031$ & $1.174 \pm 0.034$ & $0.040 \pm 0.030$ & $0.023 \pm 0.021$ \\
\hline DP & $71.368 \pm 0.696$ & $72.326 \pm 0.396$ & $72.100 \pm 0.434$ & $0.231 \pm 0.390$ & $-0.216 \pm 0.270$ \\
\hline SP & $10.466 \pm 0.283^{\mathrm{a}}$ & $10.268 \pm 0.161^{\mathrm{ab}}$ & $9.816 \pm 0.177^{b}$ & $-0.354 \pm 0.159^{*}$ & $-0.134 \pm 0.125$ \\
\hline BP & $13.315 \pm 0.321$ & $13.199 \pm 0.183$ & $12.782 \pm 0.200$ & $-0.301 \pm 0.180$ & $-0.134 \pm 0.124$ \\
\hline IFR & $2.982 \pm 0.115$ & $3.119 \pm 0.066$ & $2.962 \pm 0.072$ & $-0.044 \pm 0.065$ & $-0.076 \pm 0.045$ \\
\hline FMP & $22.250 \pm 0.816$ & $21.906 \pm 0.464$ & $21.996 \pm 0.508$ & $-0.077 \pm 0.456$ & $0.080 \pm 0.316$ \\
\hline LMP & $53.865 \pm 0.711$ & $54.443 \pm 0.405$ & $55.233 \pm 0.443$ & $0.708 \pm 0.398$ & $0.203 \pm 0.277$ \\
\hline RLF & $2.745 \pm 0.162$ & $2.721 \pm 0.092$ & $2.704 \pm 0.101$ & $-0.020 \pm 0.091$ & $-0.003 \pm 0.063$ \\
\hline CL & $90.528 \pm 0.625$ & $91.422 \pm 0.356$ & $90.819 \pm 0.390$ & $-0.025 \pm 0.351$ & $-0.342 \pm 0.242$ \\
\hline RNS & $14.540 \pm 0.110$ & $14.736 \pm 0.063$ & $14.754 \pm 0.069$ & $0.087 \pm 0.062$ & $-0.021 \pm 0.043$ \\
\hline LEH & $6.689 \pm 0.343$ & $6.547 \pm 0.195$ & $7.005 \pm 0.214$ & $0.226 \pm 0.192$ & $0.184 \pm 0.133$ \\
\hline LEA & $27.737 \pm 0.727^{\mathrm{a}}$ & $28.934 \pm 0.414^{\mathrm{ab}}$ & $29.682 \pm 0.453^{\mathrm{b}}$ & $0.922 \pm 0.407^{*}$ & $0.101 \pm 0.284$ \\
\hline AST & $0.418 \pm 0.016^{\mathrm{A}}$ & $0.392 \pm 0.009^{\mathrm{AB}}$ & $0.369 \pm 0.010^{\mathrm{B}}$ & $-0.024 \pm 0.009 * *$ & $-0.005 \pm 0.006$ \\
\hline BFT1 & $3.534 \pm 0.130$ & $3.571 \pm 0.074$ & $3.445 \pm 0.081$ & $-0.063 \pm 0.073$ & $-0.050 \pm 0.050$ \\
\hline BFT2 & $2.769 \pm 0.097$ & $2.783 \pm 0.055$ & $2.684 \pm 0.060$ & $-0.055 \pm 0.054$ & $-0.038 \pm 0.038$ \\
\hline BFT3 & $2.013 \pm 0.087$ & $2.041 \pm 0.049$ & $2.010 \pm 0.054$ & $-0.008 \pm 0.049$ & $-0.015 \pm 0.034$ \\
\hline BFT4 & $1.870 \pm 0.104$ & $1.837 \pm 0.059$ & $1.825 \pm 0.065$ & $-0.020 \pm 0.058$ & $0.000 \pm 0.040$ \\
\hline $\mathrm{ABF}$ & $2.474 \pm 0.095$ & $2.467 \pm 0.054$ & $2.426 \pm 0.059$ & $-0.028 \pm 0.053$ & $-0.014 \pm 0.037$ \\
\hline
\end{tabular}

Data are reported as means $\pm \mathrm{SE} . * \mathrm{P}<0.05$ for lowercase superscript letters. ${ }^{*} * \mathrm{P}<0.05$ for capital superscript letters. $\mathrm{BWT}=$ birth weight; $\mathrm{DP}=$ dressing percentage; $\mathrm{SP}=$ skin percentage; $\mathrm{BP}=$ bone percentage; IFR = internal fat rate; $\mathrm{FMP}=$ fat meat percentage; $\mathrm{LMP}=$ lean meat percentage; $\mathrm{RLF}=$ ratio of lean meat to fat meat; $\mathrm{CL}=$ carcass length; RNS $=$ rib numbers; $\mathrm{LEH}=$ loin eye height; LEA $=$ loin eye area; $\mathrm{AST}=$ average skin thickness; BFT1 = backfat thickness at shoulder; BFT2 = backfat thickness at thorax-waist; BFT3 = backfat thickness at buttock; BFT4 = backfat thickness at 6-7th thorax; $\mathrm{ABF}=$ average backfat thickness. 
The association of loin eye height with genotype AA versus genotype BB tended to be statistically significant $(\mathrm{P}<0.06)$. This locus appeared to be significantly associated with additive effects on some carcass traits, such as skin percentage $(\mathrm{P}<0.05)$, loin eye area $(\mathrm{P}<$ $0.05)$, and average skin thickness $(\mathrm{P}<0.01)$.

\section{DISCUSSION}

As is well known, the sequence of a gene is an entry point into studying the gene's function (Wu et al., 2006). In this study, we analyzed the 5'-flanking region upstream of the transcriptional start site of the porcine TTID gene. Our analysis suggested that TTID expression is regulated by several transcription factors, including SP1, AP1, C/EBP $\beta$, and HES1. $\mathrm{AP} 1$ is known to be involved in regulating inflammatory responses. C/EBP $\beta$ plays important roles in many cellular responses by regulating the transcription of genes in target cells, including genes involved in cell proliferation and differentiation, tumorigenesis and apoptosis, and cell cycle regulation (Ramji and Foka, 2002). YY1 activates and represses transcription of a large number of cellular and viral genes, and plays an important role in development and differentiation (Yao et al., 1998). In addition, the expression of the transcription factor SP1 is induced by hypoxia (Szalad et al., 2009), which may be adapted to the need of muscle hypoxia in the process of TTID gene activity. We also identified one site for HES1 and a single CACCC box in the putative TTID gene promoter. HES1 belongs to the basic helix-loop-helix (bHLH) family of transcription factors and is one of the seven members of the HES gene family (HES1-7), encoding nuclear proteins that suppress transcription and affect cell proliferation and differentiation in embryogenesis (Kageyama et al., 2007). CACCC (or GGGTG)-boxes and related GC-rich elements are present in the promoters and enhancers of a large number of mammalian and viral genes, and numerous transcription factors have been identified that bind to these elements to either activate or repress gene expression (van Vliet et al., 2000). Thus, we suggest that the expression of the TTID gene may be regulated at the transcription level, with a number of transcription factors contributing to its complex regulation.

Studies have shown that the porcine TTID gene is associated with the SSC2q24-q29 QTL marker (Davoli et al., 2002). The SSC2 region is considered to have some QTLs for average backfat, average daily gain, meat androstenone content, 16-day weight, drip loss, off-flavor, pH, and also other traits (Thomsen et al., 2004; Liu et al., 2007). It is well known that density and diameter of muscle fiber are negative correlated with meat quality (Gao et al., 2009). We chose the gene TTID as a candidate gene to study and analyze because its encoded protein is an important member of the titin protein family, playing an indispensable role in stabilizing and anchoring thin filaments by binding to alpha-actinin and gamma-filamin (Salmikangas et al., 1999; Wang et al., 2013).

Identifying SNPs within important functional regions of the candidate gene to enable analyses of the association of identified SNPs with important economic traits is a very useful tool to study gene function (Wang et al., 2005). In this study, we have continued to analyze the A T978C SNP in intron 6 of the porcine TTID gene on the basis of our previous research (Wang et al., 2013) by analyzing this polymorphism in six pig breeds indigenous to China. The results indicated some differences in allele frequencies and genotype distribution among these purebred pigs: two breeds (Erhualian and Jianli pigs) were identified as having higher $A$ allele frequencies and two types of genotype distribution (AA and AB). The $A$ or $B$ allele frequencies in the other four breeds ranged from 34.6 to $65.4 \%$, and three TTID genotypes were identified 
in these four breeds. These results may have been affected by long-term breeding and high selection pressure or limited number of animals in this study.

In pig breeding, meat-quality and carcass traits are considered to be important economic characteristics (Wang et al., 2012). In this study, we analyzed the association between TTID gene polymorphisms and carcass traits in a 280-pig resource population. Association analysis showed that the skin percentage and loin eye area of pigs with an AA genotype were higher than those of pigs with a BB genotype $(\mathrm{P}<0.05)$, and that the average skin thickness of pigs with an AA genotype were significantly higher than those of pigs with a BB genotype $(\mathrm{P}<0.01)$. These results indicated that the SNP might be used as a simple genetic marker linked to QTL for predicting effects on carcass traits. Combined with results from a previous study investigating associations of gene polymorphisms with meat-quality traits (Wang et al., 2013), the $B$ allele could be beneficial to accelerate the genetic improvement of pig breeds in terms of lean growth and meat quality. According to our results, the pig TTID gene is located close to the QTLs SW240-SO226 and SW2623-SO141, affecting pH and drip, and TTID may be responsible for these two QTLs or other QTLs close to them. Therefore, we may use this site as a molecular marker that can be applied to marker assisted selection in pig breeding. However, the number of pigs analyzed was limited in this study, and other closely linked genes on SSC2 might have affected our observations. Therefore, studies on more pigs of crossbreds and purebreds are needed to confirm these association results between the PCR-HinfI-RFLP and carcass traits in this study or meat-quality traits in the previous study by Wang et al. (2013).

\section{ACKNOWLEDGMENTS}

We would like to thank the staff at Huazhong Agricultural University Jingping Pig Station, and the teachers and graduate students at Key Laboratory of Swine Genetics and Breeding, Ministry of Agriculture, for managing and slaughtering the research flocks. Research supported by the National Science and Technology Supporting Project (\#2006BAD01A08-01), the "863" National High Technology Development Project (\#2007AA10Z166), and the Hubei Province Prominent Projects of Science and Technology (\#2006AA202A01).

\section{REFERENCES}

Davoli R, Fontanesi L, Zambonelli P, Bigi D, et al. (2002). Isolation of porcine expressed sequence tags for the construction of a first genomic transcript map of the skeletal muscle in pig. Anim. Genet. 33: 3-18.

Gao RS, Gheng ZB and Yang ZH (2009). Muscle fiber types and porcine meat quality. China Anim. Husbandry Vet. Med. 4: 191-195.

Gautel M, Mues A and Young P (1999). Control of sarcomeric assembly: the flow of information on titin. Rev. Physiol. Biochem. Pharmacol. 138: 97-137.

Godley LA, Lai F, Liu J, Zhao N, et al. (1999). TTID: A novel gene at 5q31 encoding a protein with titin-like features. Genomics 60: 226-233.

Kageyama R, Ohtsuka T and Kobayashi T (2007). The Hes gene family: repressors and oscillators that orchestrate embryogenesis. Development 134: 1243-1251.

Liu BH (1998). Statistical Genomics. Linkage, Mapping and QTL Analysis. CRC Press, Boca Raton.

Liu G, Jennen DG, Tholen E, Juengst H, et al. (2007). A genome scan reveals QTL for growth, fatness, leanness and meat quality in a Duroc-Pietrain resource population. Anim. Genet. 38: 241-252.

McElhinny AS, Schwach C, Valichnac M, Mount-Patrick S, et al. (2005). Nebulin regulates the assembly and lengths of the thin filaments in striated muscle. J. Cell Biol. 170: 947-957. 
Ramji DP and Foka P (2002). CCAAT/enhancer-binding proteins: structure, function and regulation. Biochem. J. 365: 561-575.

Salmikangas P (2001). Identification and Characterization of Myotilin, a Novel Sarcomeric Protein. University of Helsinki, Helsinki.

Salmikangas P, Mykkanen OM, Gronholm M, Heiska L, et al. (1999). Myotilin, a novel sarcomeric protein with two Iglike domains, is encoded by a candidate gene for limb-girdle muscular dystrophy. Hum. Mol. Genet. 8: 1329-1336.

Salmikangas P, van der Ven PF, Lalowski M, Taivainen A, et al. (2003). Myotilin, the limb-girdle muscular dystrophy 1A (LGMD1A) protein, cross-links actin filaments and controls sarcomere assembly. Hum. Mol. Genet. 12: 189-203.

Sambrook J, Fritsch EF and Maniatis T (1989). Molecular Cloning: A Laboratory Manual. 2nd edn. Cold Spring Laboratory Press, Cold Spring Harbor.

Szalad A, Katakowski M, Zheng X, Jiang F, et al. (2009). Transcription factor Sp1 induces ADAM17 and contributes to tumor cell invasiveness under hypoxia. J. Exp. Clin. Cancer Res. 28: 129.

Thomsen H, Lee HK, Rothschild MF, Malek M, et al. (2004). Characterization of quantitative trait loci for growth and meat quality in a cross between commercial breeds of swine. J. Anim. Sci. 82: 2213-2228.

van Vliet J, Turner J and Crossley M (2000). Human Kruppel-like factor 8: a CACCC-box binding protein that associates with CtBP and represses transcription. Nucleic Acids Res. 28: 1955-1962.

Wang J, Deng CY, Xiong YZ, Zuo B, et al. (2005). cDNA cloning, sequence analysis of the porcine LIM and cysteine-rich domain 1 gene. Acta Biochim. Biophys. Sin. 37: 843-850.

Wang J, Deng CY, Xiong YZ and Zuo B (2012). Association analysis of polymorphism in intron-10 of Porcine $H K 2$ gene with meat quality and carcass traits. J. Anim. Vet. Adv. 11: 1158-1161.

Wang J, Deng CY, Xiong YZ and Zuo B (2013). Molecular characterization, expression analysis and association study with meat quality traits of porcine TTID gene. Mol. Biol. Rep. 40: 1219-1226.

Wu J, Deng CY, Xiong YZ, Zhou DH, et al. (2006). cDNA cloning and polymorphism of the porcine carbonic anhydrase III (CA3) gene. Asian Aust. J. Anim. Sci. 19: 324-328.

Xiong YZ and Deng CY (1999). Principle and Method of Swine Testing. Chinese Agriculture Press, Beijing.

Yang H, Xu ZY, Lei MG, Li FE, et al. (2010). Association of 3 polymorphisms in porcine troponin I genes (TNNI1 and TNNI2) with meat quality traits. J. Appl. Genet. 51: 51-57.

Yao YL, Dupont BR, Ghosh S, Fang Y, et al. (1998). Cloning, chromosomal localization and promoter analysis of the human transcription factor YY1. Nucleic Acids Res. 26: 3776-3783. 